\title{
An Empirical Study on Capital Structure Influencing Factors of Listed Companies in Household Appliances Industry
}

\author{
Yan Zhang ${ }^{1}$, Yulin Xia ${ }^{1}$ \\ ${ }^{1}$ The Engineering and Technical College of Chengdu University of Technology, Chengdu, Sichuan \\ Province, China
}

Keywords: Home Appliance Industry, Listed Companies, Capital Structure, Influencing Factors.

\begin{abstract}
In this paper, Chinese listed companies in household electrical appliance industry are chosen as the research object. Through principal component analysis and multiple linear regressions, the capital structure influence factors of these companies are analyzed. According to the results of this study, the paper puts forward some suggestions on the optimization of capital structure of listed companies in the appliance industry from the perspective of companies.
\end{abstract}

\section{Introduction}

Home appliance industry is a pillar industry of China's national economy. Companies in that industry need to improve their competitiveness through economies of scale, which means the demanding of increasing capital. [1] Thus, financing is the only way for them. The optimization of capital structure can help these companies to achieve better financing, and avoid unnecessary financing expenses.

Through the empirical research on capital structure influencing factors of listed Chinese home appliance companies, this paper explores main factors that influence their capital structure, and provide suggestions which can not only solve the current financing problems faced by Chinese appliance companies, but also promote the capital structure optimization of listed companies in home appliance industry. Hence, the values of these companies can be maximized.

\section{Research Design}

Sample selection. In this paper, we choose the following principles in sample selection:

Listed household electrical appliance companies listed in Classification of Listed Companies issued by China Securities Regulatory Commission are served as sample basis.

In order to ensure the consistency of data, companies listed in Shanghai and Shenzhen stock exchanges before December 31, 2012 are selected as samples.

In order to ensure the effectiveness of statistical results, ST and PT companies are excluded.

$\mathrm{B}$ shares and $\mathrm{H}$ shares listed companies are excluded.

According to above principles, total 30 listed companies are selected.

Data sources. In order to overcome the instability and deviation of short-term measurement, this paper uses data from 2012 to 2015 to do the empirical research. The original data comes from securities trading platforms like Cninf, JRJ.com and Guosen website.

Research methods. This paper uses principal component extraction method to extract main influencing factors, and then makes multiple linear regressions on these principal components to obtain the main capital structure influencing factors of listed companies in household electrical appliance industry. A decision model of capital structure is established. SPSS software is used in data analysis.

Variable design. Explained variable. In order to reflect the whole picture of the capital structure, this paper uses the total asset liability ratio as the explained variable.

Explanatory Variables. This paper puts forward relevant explanatory variables in table 2 based on previous empirical researches and the particularity of listed companies in household electrical appliance industry, 
Table 1 Variables

\begin{tabular}{|l|l|l|l|}
\hline $\begin{array}{l}\text { Type of } \\
\text { indexes }\end{array}$ & $\begin{array}{l}\text { explanatory } \\
\text { variable }\end{array}$ & index & calculation method \\
\hline \multirow{2}{*}{$\begin{array}{l}\text { size of the } \\
\text { company }\end{array}$} & $\mathrm{X}_{1}$ & Logarithm of total assets & $\operatorname{lnTA}$ \\
\cline { 2 - 4 } & $\mathrm{X}_{2}$ & Logarithm of operating income & ln MOI \\
\hline $\begin{array}{l}\text { Company } \\
\text { growth }\end{array}$ & $\mathrm{X}_{3}$ & $\begin{array}{l}\text { operating income growth rate } \\
(\%)\end{array}$ & $\begin{array}{l}\mathrm{MOIG}_{\mathrm{t}}=\left(\mathrm{MOI}_{\mathrm{t}}-\mathrm{MOT}_{\mathrm{t}-1}\right) / \mathrm{MOI}_{\mathrm{t}-1} \\
\times 100 \%\end{array}$ \\
\hline $\begin{array}{l}\text { Equity } \\
\text { structure }\end{array}$ & $\mathrm{X}_{4}$ & circulating shares ratio (\%) & $\begin{array}{l}\text { circulating shares /total share } \\
\text { capital }\end{array}$ \\
\hline \multirow{3}{*}{ Profitability } & $\mathrm{X}_{5}$ & total return on assets (\%) & net profit / total assets \\
\cline { 2 - 4 } & $\mathrm{X}_{6}$ & net assets yield (\%) & net profit / total equity \\
\cline { 2 - 4 } & $\mathrm{X}_{7}$ & earnings per share (yuan) & $\begin{array}{l}\text { net profit /outstanding ordinary } \\
\text { shares }\end{array}$ \\
\hline \multirow{2}{*}{ Solvency } & $\mathrm{X}_{8}$ & current ratio & current assets / current liabilities \\
\cline { 2 - 4 } & $\mathrm{X}_{9}$ & quick ratio & $\begin{array}{l}\text { (current assets - inventories) / } \\
\text { current liabilities }\end{array}$ \\
\hline $\begin{array}{l}\text { non-debt } \\
\text { tax shield }\end{array}$ & $\mathrm{X}_{10}$ & depreciation assets ratio (\%) & $\begin{array}{l}\text { fixed assets depreciation / total } \\
\text { assets }\end{array}$ \\
\hline
\end{tabular}

\section{Empirical Results and Analysis}

Principal Component Analysis (PCA). Applicability test. Principal component analysis requires a strong correlation between original variables. Therefore, it is necessary to test its applicability. $\mathrm{KMO}$ and Bartlett test results show that, the KMO value of 0.665 is greater than 0.5 ; the Bartlett value is 858.175; the significance level of probability $\mathrm{P}$ is 0.000 , which is less than 0 . Therefore, the above data is suitable for principal component analysis.

Constructing factor variables. The extraction of factors usually follows two principles. First, the eigenvalue should be greater than 1 as far as possible. Second, the accumulated variance contribution rate should be more than $85 \%$. Referring to the above two principles, and combining with the results of Table 2, we extract the first 6 factors as the main components, namely F1, F2, F3, F4, F5, F6. This is because the accumulated variance contribution rate of the first 6 factors is up to $93.945 \%$, retaining most information of the original variables.

Table 2 Total Variance Explained

\begin{tabular}{|l|l|l|l|l|l|l|l|l|l|l|}
\hline \multirow{2}{*}{$\begin{array}{l}\text { Com } \\
\text { pone } \\
\text { nt }\end{array}$} & \multicolumn{3}{|l|}{ initial feature } & \multicolumn{6}{|c|}{ extraction square sum load } \\
\cline { 2 - 10 } & total & $\begin{array}{l}\text { variance } \\
\%\end{array}$ & $\begin{array}{l}\text { accumula } \\
\text { tion\% }\end{array}$ & total & $\begin{array}{l}\text { variance } \\
\%\end{array}$ & $\begin{array}{l}\text { accumul } \\
\text { ation\% }\end{array}$ & total & $\begin{array}{l}\text { variance } \\
\%\end{array}$ & $\begin{array}{l}\text { accumula } \\
\text { tion\% }\end{array}$ \\
\hline 1 & 3.514 & 35.143 & 35.143 & 3.514 & 35.143 & 35.143 & 2.341 & 23.413 & 23.413 \\
\hline 2 & 2.528 & 25.281 & 60.424 & 2.528 & 25.281 & 60.424 & 2.011 & 20.113 & 43.526 \\
\hline 3 & 1.080 & 10.805 & 71.228 & 1.080 & 10.805 & 71.228 & 1.962 & 19.615 & 63.141 \\
\hline 4 & .901 & 9.012 & 80.241 & .901 & 9.012 & 80.241 & 1.063 & 10.625 & 73.766 \\
\hline 5 & .753 & 7.525 & 87.766 & .753 & 7.525 & 87.766 & 1.017 & 10.171 & 83.938 \\
\hline 6 & .618 & 6.179 & 93.945 & .618 & 6.179 & 93.945 & 1.001 & 10.007 & 93.945 \\
\hline 7 & .335 & 3.350 & 97.295 & & & & & & \\
\hline 8 & .157 & 1.567 & 98.862 & & & & & & \\
\hline 9 & .080 & .803 & 99.665 & & & & & & \\
\hline 10 & .034 & .335 & 100.000 & & & & & & \\
\hline
\end{tabular}

Factor variables explanation 
Table 3 Rotation Matrix

\begin{tabular}{|l|l|l|l|l|l|l|}
\hline & \multicolumn{6}{l}{ Component } \\
\cline { 2 - 7 } & $\mathrm{F}_{1}$ & $\mathrm{~F}_{2}$ & $\mathrm{~F}_{3}$ & $\mathrm{~F}_{4}$ & $\mathrm{~F}_{5}$ & $\mathrm{~F}_{6}$ \\
\hline $\mathrm{X}_{1}$ & .144 & -.281 & .929 & -.036 & .001 & .142 \\
\hline $\mathrm{X}_{2}$ & .231 & -.338 & .893 & -.031 & .061 & .077 \\
\hline $\mathrm{X}_{3}$ & .194 & -.015 & .038 & -.058 & .969 & -.067 \\
\hline $\mathrm{X}_{4}$ & -.014 & -.180 & .151 & -.055 & -.068 & .966 \\
\hline $\mathrm{X}_{5}$ & .840 & .286 & .028 & .007 & .233 & .004 \\
\hline $\mathrm{X}_{6}$ & .935 & -.121 & .116 & .057 & .104 & .001 \\
\hline $\mathrm{X}_{7}$ & .798 & -.045 & .288 & -.294 & -.024 & -.028 \\
\hline $\mathrm{X}_{8}$ & -.006 & .906 & -.350 & -.025 & -.017 & -.085 \\
\hline $\mathrm{X}_{9}$ & .078 & .928 & -.240 & -.065 & .003 & -.159 \\
\hline $\mathrm{X}_{10}$ & -.085 & -.067 & -.034 & .979 & -.056 & -.053 \\
\hline
\end{tabular}

According to the factor loading matrix after rotation in Table 3, factors are named as follows:

Factor 1 has maximum loads on indexes X5, X6 and X7; the correlation coefficients are 0.840, 0.935 and 0.798 respectively. These three indicators are indicators of profitability, so factor 1 can be regarded as the profitability factor.

Factor 2 has maximum loads on the indexes X8 and X9; the correlation coefficients are 0.906 and 0.928 respectively. These two indicators are solvency indicators, so factor 2 is regarded as the solvency factor.

Factor 3 has maximum loads on indexes X1 and X2; the correlation coefficients are 0.929 and 0.893 respectively. These two indicators are indexes on company scale, so it can be regarded as the scale factor.

Factor 4 has a maximum load on index X10, the ratio depreciation asset. The correlation coefficient is 0.979 , so it can be regarded as a non-debt tax shield factor.

Factor 5 has a maximum load on the growth index X3; the correlation coefficient is 0.969 . So it can be regarded as the growth factor.

Factor 6 has the maximum load on the equity structure index $\mathrm{X} 4$; the correlation coefficient is 0.966. So it can be regarded as the equity structure factor.

According to the results of above principal components analysis, and combining conclusions of previous empirical studies, the paper puts forward the following basic assumptions:

Hypothesis 1: the company's profitability is negatively related to capital structure.

Hypothesis 2: the solvency of a company is negatively correlated with the capital structure.

Hypothesis 3: firm size is positively related to capital structure.

Hypothesis 4: non-debt tax shields are negatively related to capital structure.

Hypothesis 5: firm growth is positively related to capital structure.

Hypothesis6: ownership structure and capital structure are negatively correlated.

Multiple regression analysis. This paper uses multiple regression analysis method to analyze capital structure influence factors on Chinese listed companies in home appliance industry. The scores of principal components obtained from the principal component analysis are explanatory variables; asset liability ratio is the explained variable. After the regression equation adjusts goodness of fit, $\mathrm{R} 2$ reaches $84.6 \%$; means the variable $\mathrm{F}$ can explain the variability of variable $\mathrm{Y}$ by $84.6 \%$. The significant level of $\mathrm{F}$ statistics is 0.000 , and passes the test of significance level. The DW value is $2.062<4$, indicating that residuals and independent variables are independent. Therefore, the multiple regression equation is acceptable. The regression equation is formed as following.

$$
Y=0.443-0.139 F_{2}+0.113 F_{3}-0.013 F_{4}+0.012 F_{6}
$$

Based on above results, following conclusions can be drawn:

The relationship between profitability and capital structure of listed companies is not significant, which is inconsistent with research hypothesis. This is because the serious competition in home appliance industry. The assets growth rates of some companies were significantly higher than their revenue growth rates. For example, the assets growth rate of Whirlpool was $30.47 \%$ in 2014, while its operating income growth rate was only $3.37 \%$. It shows that, though some appliance companies have 
strong profitability, they still need a lot of money to meet the needs of normal operation. As result, the relationship between profitability and capital structure of listed companies in home appliance industry is not significant.

The relationship between debt paying ability and capital structure of listed companies is significant negative, which is consistent with research hypothesis. Companies with strong solvency usually have strong liquidity. Hence, funds they needed can be provided in a short period of time. If the company uses debt financing method, there will be a certain degree of financial risk. Therefore, solvency and company's asset liability ratio has a significant negative correlation.

The scale of the listed companies is positively related with capital structure, which is consistent with research hypothesis. At present, competition in China's household electrical appliance industry is very fierce. Economies of scale are competitive advantages in competition. Extension of product scale can reduce operating costs and improve the core competitiveness of companies. Meanwhile, large scale companies generally adopt multi-operation, which can spread business risks, reduce bankruptcy possibilities, and increase debt capacities.

The non-debt tax shield is significantly negative correlated with capital structure, which is consistent with the research hypothesis. Depreciation cost can be reduced from tax. If the main purpose of debt financing is tax deduction for a company, depreciation can be used to replace debt financing and play the role of tax deduction, which will reduce the level of debt.

The growth of listed companies is positively related to capital structure, but the relation is not significant. The rapid growth of a company requires the expansion of asset scale and a large amount of capital, which cannot be met by internal retained earnings. [2] As a result, many companies choose debt financing through bank loan. However, the fierce competition in China's household electrical appliance industry leads to lower profit margins of these companies. Although the company grows, there's no obvious upward trend in its asset liability ratio. Therefore, growth and capital structure do not have significant positive correlation.

There is a positive correlation between ownership structure and capital structure of listed companies, which is inconsistent with research hypothesis. Higher proportion of tradable shares is conducive to the regulatory function of security market. Under that situation, company executives will pay more attention to the long-term development and the enhancement of company performance. As a result, it will be easier for the company to get low cost bank loans and issue corporate bonds, which will raise the asset-liability ratio.

\section{Countermeasures on Optimizing the Capital Structure of Household Electrical Appliance Companies}

Based on results of this empirical research, the author thinks that the capital structure of listed companies can be optimized from following aspects:

Paying attention to the solvency of the company. Currently, there's a serious imbalance between liabilities and long-term debt ratio of listed companies in household electrical appliance industry. For most of these companies, the proportions of long-term liabilities to total debt are $0-10 \%$; the current liabilities are quite high. This phenomenon shows unstable financial situations. High current liabilities are easy to lead cash flow difficulties and credit crisis. [3] Long term liabilities have relatively small financial risks. Therefore, companies should arrange long-term and short-term debts reasonably, and pay attention to the influence of solvency to capital structure.

Determining the size of company reasonably. The scale of home appliance industry listed companies and capital structure are significantly positive correlated. For the selected 30 listed home appliances companies, the average asset liability ratio for the last 4 years was $44 \%$. The highest ratio was $80 \%$, while the lowest was $11 \%$. The actual situations of each company are different, so company authorities need to determine company size reasonably based on actual situations. Companies with higher asset liability ratios should adjust their capital structures and reduce debt ratios appropriately, rather than blindly expand company sizes. Companies with low asset liability ratios can increase their liabilities in reasonable ranges, expand company sizes, use the financial leverage to gain benefits of financial leverage, and ultimately achieve economies of scale. 
Determining the ownership structure of company reasonably. This paper selects 30 home appliances listed companies. Among them, the highest proportion of circulating shares was $100 \%$; the lowest proportion was 21\%. Both high ratio and low ratio of traded shares have advantages and disadvantages. Companies should consider their actual situations, and reasonably determine the ownership structure, in order to play the regulatory role of securities markets, prevent the spreading of corporate control rights, protect the interests of major shareholders, improve companies' debt and equity structures, and promote the long-term development companies. [4]

Focusing on profitability and growth of the company. The empirical results show that profitability and growth do not have significant influences on the capital structure of listed companies in home appliance industry. This is directly related to characteristics of China's home appliance industry and the imperfect Chinese securities markets. [5] With the improvement of China's capital market and the introduction of relevant policies, profitability and growth will take effects on capital structure of listed companies in home appliance industry as other industries. Therefore, listed companies in household electrical appliance industry still need to focus on their profitability and growth.

In short, there are many factors affecting the capital structure of listed companies in home appliance industry. In order to determine the optimal capital structure, company authorities must start from the actual situation of the company, consider various factors affecting the capital structure, reasonably determine the equity and debt structures, as well as long-term debt and short-term debt structures, in order to minimize implementation cost and maximize company value.

\section{References}

[1] Z.F. Lu, Y. Xin, An empirical study on main factors affecting the capital structure of listed companies, J. Accounting Research. 8 (1998) 34-37.

[2] X.Y. Hong, Y.F. Shen, Empirical analysis on influencing factors of capital structure of listed companies, J. Journal of Xiamen University. 3(2000) 114-120.

[3] X. Jing, H.C. Wang, J.Y. Liu, Financial Management, China Renmin University Press, Beijing, 2012.

[4] D. Fan, X.J. Li, An analysis of factors affecting the capital structure of agricultural listed companies in light of principal component analysis and multiple linear regression, J. Communication of Finance and Accounting. 02 (2015) 41-43.

[5] T. Wang, R.H. Peng, Empirical Study on influencing factors of capital structure of listed companies: a case study of food manufacturing industry, J. Commercial Accounting. 05 (2015) 54-57. 